\title{
Study on biophysical and biochemical basis of shoot and fruit borer tolerance in brinjal
}

\author{
SHUBHAM SHUKLA ${ }^{1 *}$, DEVENDRA SINGH ${ }^{1}$, BIRBAL BAIRWA $^{1}$ AND BHANWAR LAL JAT ${ }^{2}$ \\ ${ }^{1}$ Department of Agriculture, Bhagwant University, AJMER (RAJASTHAN) INDIA \\ ${ }^{2}$ Department of Agricultural Biotechnology, Bhagwant University, AJMER (RAJASTHAN) INDIA
}

\section{ARITCLE INFO}

Received : 08.06 .2017

Revised : 01.08 .2017

Accepted : 15.08 .2017

KEY WORDS :

GCV, PCV, DFF, Cluster,

Solanum melongena
*Corresponding author:

kripa38156@gmail.com

\begin{abstract}
Brinjal or eggplant or aubergine, Solanum melongena $\mathrm{L}$. is one of the most important vegetable crops grown in India and other parts of the world. It is highly cosmopolitan and popular vegetable grown as poor man's crop in India. Brinjal, being a native to India has great variability existing in the country. However, it is highly infested by shoot and fruit borer, Leucinodes orbonalis Guen., an obnoxious pest causing fruit damage upto 92.5 per cent. The pest is very active during the summer and rainy season and often causes more than 90 per cent damage. Pesticide application is not the only solution of managing the pest as repeated use of pesticide leads to health hazards, destruction of beneficial insects, pest resurgence and environmental pollution. Thus, in order to develop varieties resistant to this pest we need to know the biophysical and biochemical traits that often result intolerance mechanism. Thirty six diverse brinjal genotypes were grown in RBD with three replications at the Vegetable Research Farm, BAC, Sabour during spring-summer season of 2015-16 and morphological and biochemical studies were performed to accomplish these objectives. The findings revealed that sufficient genetic variability was present among the genotypes which provide ample scope for selection of promising genotypes under study. Shoot borer infestation was least in pusa purple cluster (3.28\%) followed by BRBR-01 while fruit borer infestation percentage by both number and weight was least in BRBL-01. Pusa purple long was the highest yielder (1100.02g/plant) followed by BRBL-01 (1046.38g/ plant). The morphological characters such as average fruit weight, fruit/plant, yield/ plant, shoot borer infestation and fruit borer infestation percentage by number possessed high heritability coupled with high genetic advance. All the biochemical characters except leaf chlorophyll and ascorbic acid exhibited high heritability coupled with high genetic advance. Therefore, selection will be more effective for these characters since they are highly heritable and easily fixable due to additive gene effect. $\mathrm{D}^{2}$ cluster analysis grouped the thirty genotypes into 7 clusters. The inter and intra cluster distance between the genotypes under study indicate the existence of higher level of genetic divergence among them. The highest inter cluster distance was observed between cluster III (comprising of BRBL-01) and cluster IV and intra cluster distance was observed within cluster IV which suggest that hybridization between the members of these
\end{abstract}

